\title{
Use of brachytherapy in children with cancer: the search for an uncomplicated cure
}

\author{
Rafael Martínez-Monge ${ }^{1}$, Mauricio Cambeiro ${ }^{1}$, Mikel San-Julián ${ }^{2}$, \\ Luis Sierrasesúmaga ${ }^{3}$
}

\author{
${ }^{1}$ Radiation Oncology Division, Department of Oncology; \\ ${ }^{2}$ Department of Orthopaedic Surgery; \\ ${ }^{3}$ Department of Paediatrics
}

Clínica Universitaria, University of Navarra, Pamplona, Spain

Correspondence to: Dr Rafael Martinez-Monge

Radiation Oncology Division, Department of Oncology. Clínica Universitaria. University of Navarra, Avda. Pío XII s/n, 31080

Pamplona (Navarra), Spain. rmartinezm@unav.es

\begin{abstract}
Brachytherapy is a sophisticated radiation method in which radioisotopes are placed inside or at a short distance from the tumour. The volume of tissue that receives the prescribed dose of radiotherapy is therefore fairly small compared with that used in standard radiotherapy techniques. In paediatric oncology, this method of radiation delivery can have a favourable effect on several undesirable long-term side-effects that sometimes develop in children who receive radiotherapy, such as growth retardation and development of second primary tumours. Here, we describe the rationale for use of brachytherapy in children with cancer, the methods of the different brachytherapy techniques available, and the results obtained with several brachytherapy regimens in expert institutions throughout the world.
\end{abstract}




\section{DEFINITIONS AND NOMENCLATURE}

Brachytherapy is a radiation technique in which radioisotopes are placed inside or at a short distance from the tumour (brachios means short in classic Greek). In intracavitary brachytherapy (used in gynaecological cancers), radioactive sources are placed inside body cavities, whereas in interstitial brachytherapy (used in soft-tissue sarcomas), radioactive material is placed directly through the tissues (figure 1). Radioactive sources can be either withdrawn after a specified dose has been delivered (temporary) or left to decay inside the body (permanent). Brachytherapy can also be classified according to the prescribed dose rate as high-dose-rate $(>12 \mathrm{~Gy} / \mathrm{h})$, medium-dose-rate $(2-12 \mathrm{~Gy} / \mathrm{h})$, or low-dose-rate $(<2 \mathrm{~Gy} / \mathrm{h})$. Finally, pulsed-dose-rate brachytherapy refers to the administration of remote afterloading brachytherapy over a few minutes (pulse) per interval, typically 1-2 Gy every 1-4 h during several days, whereas intraoperative highdose-rate brachytherapy is the administration of a single dose of irradiation during the surgical procedure.

The planning target volume refers to the volume of tissue that needs to be irradiated to ensure that the target receives the prescribed dose; ${ }^{1}$ the clinical target volume is the tissue volume presumed to contain microscopic disease at a specific probability level; and the irradiated volume refers to the volume of tissue that receives a dose of radiotherapy meant to be biologically relevant because of the inaccuracies of the radiation techniques.

\section{POTENTIAL ADVANTAGES OF BRACHYTHERAPY}

Brachytherapy differs from external-beam radiotherapy in ways that can be advantageous for children. For instance, the planning target volume in brachytherapy is smaller than that in external-beam radiotherapy. Because no allowances need to be made for movement of internal organs, movement of patients, or errors in set-up, the brachytherapy planning target volume closely approximates the clinical target volume. Furthermore, the irradiated volume is also smaller than that for external-beam radiotherapy because brachytherapy irradiates from the centre of the clinical target volume outwards and the dose falls off at a rate that is inversely proportional to the square of the distance. As a result, late complications with a strong relation to a dosevolume effect, such as growth retardation ${ }^{2-4}$ or second primary tumours, ${ }^{5-13}$ can be kept to a minimum. Brachytherapy is also usually a much quicker treatment than externalbeam radiotherapy (ie, minutes or days vs weeks), and the shorter time of treatment allows this procedure to be integrated more easily than other radiation techniques into interdisciplinary treatment programmes with surgery and multiagent chemotherapy.

\section{TECHNIQUES USED IN CHILDREN}

The brachytherapy techniques used in children are similar to those applied in adults with some modifications because of anatomical constraints or to keep late complications to a minimum. Although no dosimetric system can be firmly advocated as the gold standard in the treatment of tumours in children, soft-tissue sarcomas in small children that are located in areas adjacent to crucial structures (eg, growth plates) can benefit from shorter intercatheter spacing and reduced margins around the clinical treatment volume. These two methods have been recommended by the American Brachytherapy 
Society. ${ }^{14}$ Use of small spaces between catheters keeps the amount of tissue volume that receives brachytherapy doses above the prescribed isodose as small as possible. Similarly, vaginal tumours in children are treated with smaller custom-made applicators than are those in adults; and, in addition, doses are prescribed closer to the surface. Nag and Tippin ${ }^{15}$ recommend that doses be prescribed at $2 \mathrm{~mm}$ depth for girls younger than 1 year, at $3 \mathrm{~mm}$ for girls aged 1 to 3 years, at $4 \mathrm{~mm}$ for girls aged 3 to 6 years, and at 5 $\mathrm{mm}$ for girls older than 6 years. This recommendation results in a vaginal mucosal dose of about $60 \mathrm{~Gy}$ for most patients.

The type of brachytherapy used depends on the age of the patient and on the availability of equipment. Although the most common technique is low-dose-rate brachytherapy with iridium-192 that is afterloaded manually and removed after treatment, use of this technique has been associated with radiation exposure to the children's caregivers when constant supervision is needed. For this reason, this technique is not ideal for treatment of very young children. Remote afterloading technology has been used to reduce the radiation exposure to caregivers, and other new modalities such as high-dose-rate, pulsed-dose-rate, and intraoperative high-dose-rate brachytherapy almost eliminate the risk of radiation exposure. Furthermore, the radioactive sources in this equipment are retracted into the main safe during planned interruptions or in the event of an accidental entry into the treatment room. Other radiation sources such as iodine-125 can be used as an alternative to ${ }^{192} \mathrm{Ir}$, especially in very young children, because of reduced radiation exposure to caregivers and to extremely radiosensitive structures (eg, gonads). ${ }^{16,17}$ In the use of ${ }^{125} \mathrm{I}$, thin sheets of lead applied over the treated area or standard lead aprons $(0.25$ $\mathrm{mm}$ lead equivalent) can adequately shield visitors. Radioisotopes such as gold-198 and californium-252 have also been used infrequently.

\section{Low-dose-rate brachytherapy}

\section{Temporary}

In interstitial low-dose-rate brachytherapy, plastic catheters are inserted into the target volume with the aid of bore needles, usually at the time of resection (open-cavity procedure). The clinical target volume is determined jointly by the surgical and radiation oncology teams. The tumour bed is also seen directly, thereby avoiding a geographical miss. The procedure can also be done postoperatively on superficial sites (closed-cavity procedure). The implantation is followed by a dosimetric analysis, usually with a set of orthogonal radiograph films or CT images, once the child is ready for transportation. Manual or remote afterloading of radioactive sources (usually ${ }^{192} \mathrm{Ir}$ ) is usually done 3-5 days after excision to allow healing to begin, as recommended by experts who have suggested that the rate of wound breakdown can be lessened by use of a delayed loading policy. ${ }^{18}$ In intracavitary brachytherapy, custom-built intracavitary vaginal applicators are generally used because standard-sized applicators are usually inappropriate for young girls. Unlike interstitial brachytherapy, low-dose-rate intracavitary brachytherapy for vaginal tumours is done post-operatively after healing is complete; and loading can therefore be done immediately with either ${ }^{192} \mathrm{Ir}$ or caesium137 sources.

If low-dose-rate brachytherapy is used as the only adjuvant radiotherapy, doses of 4560 Gy are commonly used with rates of $0.4-0.6 \mathrm{~Gy} / \mathrm{h}$ over $4-6$ days. If it is combined with $40-50$ Gy of external-beam radiotherapy, then the dose is reduced to $15-25 \mathrm{~Gy}$. 


\section{Permanent}

In permanent interstitial brachytherapy, low-activity $(0.45-0.60 \mathrm{U}){ }^{125} \mathrm{I}$ seeds are commonly used, which are usually embedded at $1.0 \mathrm{~cm}$ intervals in vicryl suture material and sewn directly into the tumour bed. If the target volume contains gross palpable tumour or if surgery is discouraged, the ${ }^{125} \mathrm{I}$ seeds are inserted into the tumour through hollow needles. ${ }^{16}$ The low photon energy of ${ }^{125} \mathrm{I}(28 \mathrm{KeV})$ makes admission to hospital, a shielded room, and strict visitor restrictions unnecessary; however, some mild radiation precautions are sometimes needed for accompanying women who are pregnant or for other children during the first few months after implantation.

Because only a few children are given this technique, no prescription guidelines are followed universally. In interstitial brachytherapy, the dose is usually prescribed at the periphery of the implant (if no gross tumour is visible) or at the periphery of the gross tumour to make sure that the chosen clinical target volume or gross tumour volume receives at least the prescribed dose. This prescription isodose is called the reference isodose in the Paris System ${ }^{19}$ and the minimum target dose in the International Commission on Radiation Units (ICRU) and Measurements Number 58 recommendations. ${ }^{20}$ The prescription isodose is usually a proportion of the dose reached at the centre of the implant, called basal dose in the Paris system or mean central dose in the ICRU Number 58 system.

\section{Pulsed-dose-rate or high-dose-rate temporary brachytherapy}

In pulsed-dose-rate and high-dose-rate brachytherapy, the catheters (or applicators) are inserted into the tumour site in the same way as in low-dose-rate brachytherapy. Most equipment used in these techniques now allows three-dimensional CT-based dosimetry (figure 2) with beam's eye view and dose-volume histograms. Furthermore, one stepping source can be used in most remote-controlled afterloaders, allowing treatment to be optimised through the use of modifiable dwell times. The treatments are done over a few days in pulsed dose rate and over a few minutes in high dose rate.

Because only a few children are given these techniques, no reliable prescription guidelines have been issued. The few centres that have reported treatment with high dose rate brachytherapy have used small fractions of 3-5 Gy with or without externalbeam radiotherapy. The dose is generally prescribed at $0.5 \mathrm{~cm}$ tissue depth for resected tumour beds and at the periphery of the target volume for gross tumour. For cylinders placed within the cavity, the dose can be specified at various depths depending on the age of the child and the diameter of the cylinder to limit the vaginal surface dose to acceptable levels.

\section{Intraoperative high-dose-rate brachytherapy}

Intraoperative high dose rate brachytherapy (figure 3) shares some of the advantages of open-cavity low-dose rate brachytherapy-eg, the clinical target volume is determined jointly by the surgical and radiation oncology teams, thereby reducing the risk of a geographical miss. Hollow plastic catheters are inserted into special flexible applicators that are secured onto the surgical surface. The treatment is delivered with one highactivity ${ }^{192} \mathrm{Ir}$ source. When the intraoperative high-dose-rate treatment is finished, the surgical team completes the surgical procedure. The main advantage of this technique is that unaffected tissues are either displaced from the irradiated area or shielded, if 
clinically applicable. Risk of catheter displacement is also reduced, since treatment is given in a short time to a patient who has been anaesthetised. Doses are usually restricted to 10-15 Gy prescribed to $0.5 \mathrm{~cm}$ depth within the target tissues because of the radiobiological disadvantage of using large single-dose fractions. If possible, intraoperative high-dose-rate brachytherapy should be combined with external-beam radiotherapy and not used on its own.

\section{Specialised brachytherapy techniques}

Ocular brachytherapy is a type of low-dose-rate temporary brachytherapy in which an eye plaque with radioactive material is placed on the episcleral surface of the eye. In children, this type of treatment has been used mainly in management of retinoblastoma. Plaques are usually made of gold or other shielding material that protects the retina and other structures adjacent to the tumour. Radioactive plaques are sewn onto the sclera lying over the tumour and are left in place until the prescribed dose has been reached, usually in 2-4 days. ${ }^{125} \mathrm{I}$ is the preferred radioisotope in many institutions because it has a lower ratio of dose to depth than other radioisotopes such as cobalt-60 or ${ }^{192} \mathrm{Ir}$. This lower penetration keeps the irradiation of nearby eye structures to a minimum. Ruthenium106 plaques have also been used in treatment of selected shallower tumours. Typical brachytherapy doses for retinoblastoma are 35-55 Gy, which are prescribed to the tumour apex at a rate of $0.3-0.6 \mathrm{~Gy} / \mathrm{h}$.

Intralesional or intracystic brachytherapy refers to the instillation of liquid radioactive compounds into the tumour. Different radioisotopes specially prepared for injection, such as yttrium-90, ${ }^{198} \mathrm{Au}$, and phosphorus-32, have been used. In children, this sophisticated technique has been used in management of craniopharyngiomas that are mainly cystic. Large radiation doses in the range of 150-250 Gy are prescribed at the cyst wall. Because of the proximity to crucial structures such as the optic chiasm and the hypophyseal stalk, only radioisotopes with a very short reach can be used. The pure $\beta$-emitters ${ }^{32} \mathrm{P}$ and ${ }^{90} \mathrm{Y}$, which have average tissue penetrations of only $0.8 \mathrm{~mm}$ and 1.1 $\mathrm{mm}$, respectively, are the most frequently used radionucleides.

\section{DISEASE-SPECIFIC OUTCOMES}

Table 1 shows the results of studies of low-dose brachytherapy in children with brain tumours. $^{21,22}$ Sneed and coworkers ${ }^{22}$ reported on 28 patients with brain tumours who were given either ${ }^{192}$ Ir or ${ }^{125}$ I permanent low-dose-rate brachytherapy with a CT/MRI stereotactic method, and found that the mean Karnofsky performance status was 88 (SD 9) at the time of brachytherapy, 87 (7) at 3 years, and 87 (9) in the 11 patients alive at 6-12 years' follow up. None of these long-term survivors are dependent on steroids.

Several studies ${ }^{23-25}$ have reported the outcomes for 27 girls with clear-cell adenocarcinoma of the vagina who were treated between 1972 and 1986 who received surgery with pelvic lymphadenectomy and then ovarian transposition. External-beam radiotherapy was then added in patients with bulky tumours, nodal involvement, or stage III-IV disease (table 2).

Around $80 \%$ of children with craniopharyngioma have been shown to respond to treatment in two studies ${ }^{26,27}$ (table 2). In the first study, ${ }^{26} 49$ patients (15 of whom were younger than 16 years) were given stereotactic ${ }^{32} \mathrm{P}$ intracavitary radiotherapy. The 
second study ${ }^{27}$ used intracavitary ${ }^{32} \mathrm{P}$ or ${ }^{90} \mathrm{Y}$, and noted that the side-effects were consistent with damage to the brain stem or cranial nerves with intracystic radioisotopes (table 2).

Intraoperative high-dose-rate brachytherapy has been used to improve local control in children with Ewing's sarcoma and primitive neuroectodermal tumours (table 2). ${ }^{28-30}$ Other studies ${ }^{31-36}$ have also shown no noticeable complications and similar rates of long-term local control after intraoperative high-dose-rate radiotherapy (table 2).

In the study by Nakamura and colleagues, ${ }^{34} 15$ children with stage IV nasopharyngeal lymphoepithelioma and one with stage III nasopharyngeal lymphoepithelioma were given high-dose-rate brachytherapy between May, 1992, and May, 2000. Children received two sessions of high-dose-rate brachytherapy (5 Gy) 1 week apart prescribed at $10 \mathrm{~mm}$ from the applicators. Most patients responded well (table 2).

Most $(86 \%)$ of the 141 patients in the study by Shields and colleagues ${ }^{35}$ received ${ }^{125} \mathrm{I}$ eye plaques with a median brachytherapy dose of 40 Gy: 60 (29\%) of 208 tumours were treated as first-line and $148(71 \%)$ as salvage treatment. Recurrence was detected at a mean of 8 months (range 2-51). The St Jude series ${ }^{36}$ also reported excellent results for local control (table 2).

Fontanesi and colleagues ${ }^{37}$ showed that of seven patients with primary rhabdomyosarcoma, four were given brachytherapy alone at a rate of $0.4-0.5 \mathrm{~Gy} / \mathrm{h}$, one was given brachytherapy alone at $1.2 \mathrm{~Gy} / \mathrm{h}$ and the other two, who had gross residual disease, received brachytherapy combined with external-beam radiotherapy. Of the five patients given brachytherapy alone (patients treated at $1.2 \mathrm{~Gy} / \mathrm{h}$ ), one developed soft tissue necrosis and the other four patients had no noticeable complications; all were alive and had had no local recurrence at the latest follow-up. Neither of the patients with primary tumours given brachytherapy and external-beam radiotherapy achieved local control, and both died of disease. Of the seven patients with recurrent or metastatic rhabdomyosarcoma, six were given brachytherapy alone and one was also given external-beam radiotherapy. Five of the seven patients achieved local control, although five developed distant disease within 12 months. One patient developed vaginal necrosis and another started bleeding at the catheter site at the time of catheter removal. The only patient to survive longer than 12 months developed soft-tissue necrosis that needed treatment with hyperbaric oxygen.

In a study by Curran and colleagues, ${ }^{38}$ patients who were given first-line treatment received ${ }^{192}$ Ir low-dose-rate brachytherapy only, two of three patients with recurrent disease after radiotherapy were given permanent implants and one was given temporary brachytherapy. Although most patients achieved local control (table 3), three died of disease. Chronic sequelae included telangiectasia and early tooth decay, fibrosis of the floor of the mouth with mild speech impairment, and shoe-size discrepancy.

In a series of reports, ${ }^{28-30} 20$ children with rhabdomyosarcoma given intraoperative high-dose-rate brachytherapy were assessed. One patient developed an infarcted bowel about 1 year after surgery and received intraoperative high-dose-rate brachytherapy to the right buttock (15 Gy) and retroperitoneum (12 Gy) for an alveolar rhabdomyosarcoma. He also received postoperative external-beam radiotherapy to 45 Gy. Another patient was diagnosed with hepatic veno-occlusive disease after intraoperative high-dose-rate brachytherapy to the porta hepatis followed by 24 Gy whole-abdominal radiotherapy for a massive retroperitoneal embryonal 
rhabdomyosarcoma. Nag and colleagues ${ }^{32,33}$ also reported on three patients with rhabdomyosarcoma involving the pelvic sidewall on one or both sides treated with intraoperative high-dose-rate brachytherapy and external-beam radiotherapy, although in one case, external-beam radiotherapy was not given. One patient with recurrent vaginal rhabdomyosarcoma in the inguinal and pelvic nodes needed orthopaedic pinning of her femoral subcapital epiphysis and construction of a neobladder secondary to ureteral obstruction.

Table 3 shows the results of studies of brachytherapy in patients with rhabdomyosarcoma. ${ }^{2,23,25,28-30,32,33,37-47}$ In a prospective trial of high-dose-rate brachytherapy alone, three of the 12 very young girls with rhabdomyosarcoma had grade 3-4 morbidity, and three developed grade-2 morbidity. ${ }^{39,40}$ Vaginal stenosis developed 10 years later in one girl, and periurethral fibrosis developed 8 years later in another when they entered puberty.

In a study ${ }^{43}$ of 20 children with primary head and neck non-orbital rhabdomyosarcoma, ten had non-surgical complications, including malocclusion in four children and atrophy of the muscle flap, rhinolalia aperta, articulation disorders, epiphora and dental problems, trismus, craniofacial asymmetry, and velopharyngeal insufficiency in the other six. In another report, ${ }^{42}$ patterns of failure were assessed in 24 patients with rhabdomyosarcoma (table 3). Most patients were treated with low-dose-rate brachytherapy, and some received pulsed-dose-rate brachytherapy. Five of the six patients who had relapse in the residual area had gross total or incomplete surgery, suboptimal position brachytherapy mold, or both. Long-term sequelae in a study by Buwalda and colleagues ${ }^{41}$ included mild swallowing disorders in one child; dental disturbances of multiple elements in three children, which were found in all four quadrants and without a preference for the site of the treated lesion; and trismus in one child. One patient developed a second primary cancer, a myofibrosarcoma originating within the treatment field, 7.8 years after brachytherapy treatment.

Nag and colleagues ${ }^{23,44,45}$ reported that 18 of 23 children with bladder or prostate tumours were given low-dose-rate brachytherapy as first-line treatment and five received this technique as salvage treatment. Of the 18 patients treated with first-line brachytherapy, 11 are alive, ten with organ preservation (table 3 ). Of the five children given salvage brachytherapy, one had locoregional failure and one had distant failure; three patients are alive and without local failure at 4, 9, and 11 years follow-up.

Gerbaulet and colleagues ${ }^{25,46,47}$ reported on 17 girls with rhabdomyosarcoma of the vagina treated with low-dose-rate brachytherapy (table 3). Before brachytherapy, eight patients underwent oophoropexy. 12 pubescent or postpubescent girls were investigated for long-term sequelae (follow-up longer than 10 years). 11 of the 12 patients have had a normal puberty, and two of them have had a total of three healthy children delivered by caesarian-section (these patients had not undergone ovarian transposition). One patient had a partial ovarian insufficiency (oophoropexy was not done) with an estimated dose to the bilateral ovaries of 10-15 Gy in 7 days. One patient underwent hysterectomy after low-dose brachytherapy. 11 patients had normal menses, and ten had normal menarche (one after hormonal replacement). Five girls had only minor telangiectasias; three are sexually active. Three have had minimal vaginal sequelae, which needed surgery to allow sexual intercourse. 15 of the 17 girls were cured of their disease. 
The largest series ${ }^{48}$ done in soft-tissue sarcoma included 27 children with primary disease and four with recurrent disease. The children were implanted with ${ }^{125} \mathrm{I}$ or ${ }^{192} \mathrm{Ir}$ in temporary or permanent implants. Of the 27 patients treated as first-line treatment, ten received brachytherapy alone and the remaining 17 were given brachytherapy and external-beam radiotherapy (table 4$){ }^{23,48-51}$

\section{CONTROVERSIAL ISSUES}

The data presented in the previous section comprises the experience generated by a handful of expert institutions in a fairly small number of patients, and therefore the results are sometimes criticised for not having the necessary level of evidence needed in modern medicine. In fact, the level of evidence derived from the brachytherapy studies ranges from III to $\mathrm{V}$, which corresponds to a grade $\mathrm{C}$ of recommendation for therapy. ${ }^{52}$ This low level of evidence is not surprising, however, taking into account that the incidence of all types of cancer in children aged younger than 20 years during 2002 was 16.5 per 100000 people $^{53}$ according to the US Surveillance, Epidemiology and End Results (SEER) programme, with soft-tissue sarcomas (International Classification of Childhood Cancers [ICCC] group IX) - the group in which brachytherapy experience is the largest - ranking fifth with an incidence of 1.1 cases per 100000 and a proportion of less than $8 \%$ of all the tumours diagnosed in children. It should be noted that the use of brachytherapy in leukaemia (ICCC, group I), lymphomas and reticuloendothelial neoplasms (ICCC group II), and CNS and miscellaneous intracranial and intraspinal neoplasms (ICCC group III) that account for more than $60 \%$ of the cancers diagnosed in children is anecdotal. ${ }^{17,21,22}$

However, brachytherapy has some potential advantages. The small size of the brachytherapy planning target volume could keep to a minimum the development of late complications that have a strong relation to a dose-volume effect such as growth retardation $^{2-4}$ or second primary tumours. ${ }^{5-13}$ In fact, the literature reviewed ${ }^{14-17,21-51,54,55}$ shows only one case ${ }^{43}$ of brachytherapy-induced second primary cancer. Whether this fact confirms the above-mentioned hypothesis or simply reflects the small number of patients treated is unclear.

This finding could be especially important because second primary tumours are regarded as the most emotionally and physically devastating complication afflicting children who survive cancer. ${ }^{56}$ The cumulative incidence of second primary tumours in survivors of cancer in childhood is about $3 \%,{ }^{9,10}$ a low incidence rate when the fact that more than $75 \%$ of children with cancer are expected to be long-term survivors is taken into account. ${ }^{53}$

The risk of developing a radiation-induced second primary tumour is higher when treatment is delivered at a younger age, ${ }^{7}$ and the risk increases with longer follow-up. Radiation-induced second primary cancers usually occur after a long latency period (more than 10 years for bone tumours, 15-20 years for breast cancer), and the risk remains constant thereafter. Some tissues such as the female breast and the thyroid gland might be more sensitive to radiation and are at risk to develop second primary tumours at quite low doses; other tissues such as bone could be susceptible only at higher doses. The risk of development of second primary tumours of the female breast, ${ }^{5}$ bone, ${ }^{8,12}$ and thyroid6 is known to be related to the dose of radiation delivered during childhood. For instance, the risk of development of second primary tumours of the bone is 40 times higher after doses of more than 60 Gy than after lower doses, and the 
relative risk of cancer of the female breast is 5.9 times higher after radiation doses of 20-40 Gy than after doses of less than $20 \mathrm{~Gy} .{ }^{5}$ As a result, external-beam radiotherapy techniques for cancer in childhood, such as those implemented by the Intergroup Rhabdomyosarcoma Study or by several Intergroups in Hodgkin's lymphoma have gradually reduced the radiation volume and dose, and have moved towards a higher conformality; ${ }^{54}$ therefore, the current external-beam radiotherapy and brachytherapy approaches to treating cancer in childhood are quite similar.

Because of the smaller clinical target volume irradiated with brachytherapy (figure 4), developing organs could be less susceptible to growth alteration than after conventional radiotherapy. Organ development depends not only on exposure to cytotoxic therapy but also on the type of organ architecture (ie, the possibility that the unaltered organ tissue compensates for the damage received to the altered fraction of the same organ) and on the stage of development at which the damaging event takes place. For instance, brain damage could be unrecoverable in patients aged younger than 7 years, a time at which CNS development is thought to be completed, but could be somewhat better tolerated in older children. Unfortunately, no randomised trials have compared brachytherapy and external-beam radiotherapy and focused on long-term complications.

Another potential advantage of brachytherapy is the small size of the irradiated volume. Although as noted before, the radiation dose received during childhood is associated directly with the risk of developing a second primary cancer, other reports have questioned this fact. Dorr and Herrmann ${ }^{57}$ reported that about $80 \%$ of 203 radiationinduced second primary tumours (across all ages) were seen in the volume receiving less than 6 Gy $(2.5 \mathrm{~cm}$ inside to $5 \mathrm{~cm}$ outside the margin of the planning target volume). The brachytherapy clinical target volume will probably be even smaller in the future. Until recently, the generally accepted view of treating sarcomas in children with radiation was to cover large volumes with adequate margins. ${ }^{23-25}$ However, in some chemosensitive cancers in childhood, for example, rhabdomyosarcoma, such an approach might not be necessary. Data from institutions that do paediatric brachytherapy routinely suggest that radiotherapy of the postchemotherapy volume (figure 5) with 1-2 cm margins is adequate. ${ }^{15,46}$ Although no formal limits in terms of dose and volume exist in paediatric brachytherapy, limiting the volume implant to less than $50 \mathrm{~mL}$ and the total dose to less than 55-60 Gy would seem prudent. Investigators at the Institut Gustav Roussy recommend avoidance of large-volume high-dose implants (more than $70 \mathrm{~Gy}$ ) and dose rates greater than $1 \mathrm{~Gy} / \mathrm{h}$.

Furthermore, brachytherapy could also be integrated better into multidisciplinary programmes that include multiagent chemotherapy. Needless to say, chemotherapy is of paramount importance in many childhood tumours such as rhabdomyosarcoma, Ewing's family, and others. Because of the short treatment time, brachytherapy could avoid harmful delays (that might be needed during external-beam radiotherapy) in the delivery of cytotoxic therapy because of unrecovered bone-marrow function. Such avoidance of delays could allow the dose intensity achieved with chemotherapy to be maintained or even increased. The amount of bone-marrow reserve is also surely higher after brachytherapy than after wide-field external-beam radiotherapy, which would allow effective cytotoxic retreatment in children who recur after initial treatment or in candidates for high-dose regimens with bone-marrow support.

Finally, most of our current understanding of brachytherapy in children derives from the use of low-dose-rate regimens. However, low-dose-rate brachytherapy is slowly being replaced by emerging brachytherapy techniques such as pulsed-dose-rate and high-dose- 
rate brachytherapy because of better compliance with radiation safety regulations and more sophisticated treatment planning equipment. High-dose-rate brachytherapy has a more unfavourable profile of toxic effects compared with low-dose-rate and pulseddose-rate brachytherapy because of the use of larger doses per fraction that restrict the repair of late reacting tissues in a growing individual. For that reason, the high-dose-rate fractions used in brachytherapy in children (3-4 Gy) are usually smaller than those in adults. For instance, the linear quadratic model $^{58}$ predicts that the high-dose-rate-only regimen used at the Ohio State University, Columbus, OH, USA, of 123 Gy fractions given twice a day (total dose 36 Gy) is equivalent to 39 Gy and 43 Gy delivered with standard fractionation ( 2 Gy per day) assuming standard $\alpha / \beta$ ratios for acute and latereacting tissues of 10 and 3 , respectively. If the same total dose of 36 Gy were delivered with nine fractions of $4 \mathrm{~Gy}$, the equivalent total dose for late-reacting tissues standardised for $2 \mathrm{~Gy}$ fractions would rise to $50.4 \mathrm{~Gy}$.

Based on the current level of evidence, brachytherapy cannot be regarded as the gold standard for any tumour in children. However, the reported results suggest that it seems to be especially suited for children with a soft-tissue sarcoma or rhabdomyosarcoma in whom organ preservation and function is a priority and in whom adequate tumour reduction can be achieved with resection, multiagent chemotherapy, or both.

In conclusion, brachytherapy, if feasible, is an attractive alternative to conventional radiotherapy when radiotherapy is needed for the treatment of children with tumours. Brachytherapy probably decreases the probability of late complications, including the development of second primary tumours compared with external-beam radiotherapy. High-dose-rate and pulsed-dose-rate brachytherapy will probably replace low-dose-rate brachytherapy; therefore, fractionation regimens that are biologically equivalent need to be developed and long-term effects need to be addressed.

\section{SEARCH STRATEGY AND SELECTION CRITERIA}

A thorough PubMed search of title words was done between 1966 and 2005, combining a set of population-based search terms (pediatric, pediatrics and their homophones, paediatric and paediatrics, as well as child, children, and childhood), a set of radiationbased search terms (brachytherapy or curietherapy), and a set of search terms containing specific paediatric tumours (rhabdomyosarcoma, retinoblastoma, etc). There were no restrictions on language.

\section{CONFLICT OF INTEREST}

We declare no conflicts of interest.

\section{ACKNOWLEDGMENTS}

We thank David Carpenter for editorial assistance. 


\section{REFERENCES}

1. International Commission on Radiation Units and Measurements. Prescribing, recording and reporting photon beam therapy. ICRU Report 62. Bethesda: International Commission on Radiation Units and Measurements, 1999.

2. Fromm M, Littman P, Raney RB, et al. Late effects after treatment of twenty children with soft tissue sarcomas of the head and neck: experience at a single institution with a review of the literature. Cancer 1986; 57: 2070-76.

3. Jaffe N, Toth BB, Hoar RE, et al. Dental and maxillofacial abnormalities in longterm survivors of childhood cancer: effects of treatment with chemotherapy and radiation to the head and neck. Pediatrics 1984; 73: 816-23.

4. Pais RC, Ragab AH. Rhabdomyosarcomas in infancy. In: Maurer HM, Ruymann FB, Pochedly C, eds. Rhabdomyosarcoma and related tumors in children and adolescents. Boca Raton: CRC Press, 1991: 373-84.

5. Bhatia S, Robison LL, Oberlin O, et al. Breast cancer and other second neoplasms after childhood Hodgkin's disease. N Engl J Med 1996; 334: 745-51.

6. de Vathaire F, Hardiman C, Shamsaldin A, et al. Thyroid carcinomas after irradiation for a first cancer during childhood. Arch Intern Med 1999; 159: 271319.

7. Garwicz S, Anderson H, Olsen JH, et al. Second malignant neoplasms after cancer in childhood and adolescence: a population-based case-control study in the 5 Nordic countries. The Nordic Society for Pediatric Hematology and Oncology. The Association of the Nordic Cancer Registries. Int J Cancer 2000; 88: 672-78.

8. Hawkins MM, Wilson LM, Burton HS, et al. Radiotherapy, alkylating agents, and risk of bone cancer after childhood cancer. J Natl Cancer Inst 1996; 88: 270-78.

9. Neglia JP, Friedman DL, Yasui Y, et al. Second malignant neoplasms in five-year survivors of childhood cancer: childhood cancer survivor study. J Natl Cancer Inst 2001; 93: 618-29.

10. Olsen JH, Garwicz S, Hertz H, et al. Second malignant neoplasms after cancer in childhood or adolescence. Nordic Society of Paediatric Haematology and Oncology Association of the Nordic Cancer Registries. BMJ 1993; 307: 1030-36.

11. Perkins JL, Liu Y, Mitby PA, et al. Nonmelanoma skin cancer in survivors of childhood and adolescent cancer: a report from the childhood cancer survivor study. J Clin Oncol 2005; 23: 3733-41.

12. Tucker MA, D'Angio GJ, Boice JD Jr, et al. Bone sarcomas linked to radiotherapy and chemotherapy in children. N Engl J Med 1987; 317: 588-93.

13. Zang EA, Wynder EL. Differences in lung cancer risk between men and women: examination of the evidence. J Natl.Cancer Inst 1996; 88: 183-92.

14. Nag S, Shasha D, Janjan N, et al. The American Brachytherapy Society recommendations for brachytherapy of soft tissue sarcomas. Int J Radiat Oncol Biol Phys 2001; 49: 1033-43.

15. Nag S, Tippin DB. Brachytherapy for pediatric tumors. Brachytherapy 2003; 2: 131-38.

16. Marquez CM, Larson DA, Roberts LW. Iodine-125 implant of a rhabdomyosarcoma of the prostate in a 20-month-old boy. Endocurieth Hyperth Oncol 1992; 8: 49-52.

17. Healey EA, Shamberger RC, Grier HE, et al. A 10-year experience of pediatric brachytherapy. Int J Radiat Oncol Biol Phys 1995; 32: 451-55.

18. Ormsby MV, Hilaris BS, Nori D, Brennan MF. Wound complications of adjuvant radiation therapy in patients with soft-tissue sarcomas. Ann Surg 1989; 210: 9399. 
19. Pierquin B, Dutreix A, Paine $\mathrm{CH}$ et al. The Paris system in interstitial radiation therapy. Acta Radiol Oncol Radiat Phys Biol 1978; 17: 33-48.

20. International Commission on Radiation Units and Measurements. Dose and volume specification for reporting interstitial therapy. ICRU Report 58. Bethesda, MD: International Commission on Radiation Units and Measurements, 1997.

21. Etou A, Mundinger F, Mohadjer M, Birg W. Stereotactic interstitial irradiation of diencephalic tumors with iridium 192 and iodine 125: 10 years follow-up and comparison with other treatments. Childs Nerv Syst 1989; 5: 140-43.

22. Sneed PK, Russo C, Scharfen CO, et al. Long-term follow-up after high-activity ${ }^{125}$ I brachytherapy for pediatric brain tumors. Pediatr Neurosurg 1996; 24: $314-$ 22.

23. Nag S, Gerbaulet A, Lartigau E, Fontanesi J. Pediatric Tumors. In: Nag S, ed. Principles and Practice of Brachytherapy. Armonk, New York: Futura Publishing, 1997: 497-610.

24. Gerbaulet A, Panis X, Flamant F, Chassagne D. Iridium afterloading curietherapy in the treatment of pediatric malignancies: the Institut Gustave Roussy experience. Cancer 1985; 56: 1274-79.

25. Gerbaulet AP, Esche BA, Haie CM, et al. Conservative treatment for lower gynecological tract malignancies in children and adolescents: the Institut GustaveRoussy experience. Int J Radiat Oncol Biol Phys 1989; 17: 655-58.

26. Hasegawa T, Kondziolka D, Hadjipanayis CG, Lunsford LD. Management of cystic craniopharyngiomas with phosphorus-32 intracavitary irradiation. Neurosurgery 2004; 54: 813-20.

27. Voges J, Sturm V, Lehrke R, et al. Cystic craniopharyngioma: long-term results after intracavitary irradiation with stereotactically applied colloidal beta-emitting radioactive sources. Neurosurgery 1997; 40: 263-69.

28. Zelefsky MJ, LaQuaglia MP, Ghavimi F, et al. Preliminary results of phase I/II study of high-dose-rate intraoperative radiation therapy for pediatric tumors. $\mathrm{J}$ Surg Oncol 1996; 62: 267-72.

29. Merchant TE, Zelefsky MJ, Sheldon JM, LaQuaglia MB, Harrison LB. High-dose rate intraoperative radiation therapy for pediatric solid tumors. Med Pediatr Oncol 1998; 30: 34-39.

30. Goodman KA, Wolden SL, LaQuaglia MP, et al. Intraoperative high-dose-rate brachytherapy for pediatric solid tumors: a 10-year experience. Brachytherapy 2003; 2: 139-46.

31. Potter R, Knocke TH, Kovacs G, et al. Brachytherapy in the combined modality treatment of pediatric malignancies: principles and preliminary experience with treatment of soft tissue sarcoma (recurrence) and Ewing's sarcoma. Klin Paediatr 1995; 207: 164-73.

32. Nag S, Martinez-Monge R, Ruymann FB, Bauer CJ. Feasibility of intraoperative high-dose rate brachytherapy to boost low dose external beam radiation therapy to treat pediatric soft tissue sarcomas. Med Pediatr Oncol 1998; 31: 79-85.

33. Nag S, Tippin D, Ruymann FB. Intraoperative high-dose-rate brachytherapy for the treatment of pediatric tumors: the Ohio State University experience. Int $\mathrm{J}$ Radiat Oncol Biol Phys 2001; 51: 729-35.

34. Nakamura RA, Novaes PE, Antoneli CB, et al. High-dose-rate brachytherapy as part of a multidisciplinary treatment of nasopharyngeal lymphoepithelioma in childhood. Cancer 2005; 104: 525-31.

35. Shields CL, Shields JA, Cater J, et al. Plaque radiotherapy for retinoblastoma: long-term tumor control and treatment complications in 208 tumors. Ophthalmology 2001; 108: 2116-21. 
36. Merchant TE, Gould CJ, Wilson MW, et al. Episcleral plaque brachytherapy for retinoblastoma. Pediatr Blood Cancer 2004; 43: 134-39.

37. Fontanesi J, Rao BN, Fleming ID, et al. Pediatric brachytherapy: the St Jude Children's Research Hospital experience. Cancer 1994; 74: 733-39.

38. Curran WJ Jr, Littman P, Raney RB. Interstitial radiation therapy in the treatment of childhood soft-tissue sarcomas. Int J Radiat Oncol Biol Phys 1988; 14: 169-74.

39. Nag S, Tippin D, Ruymann FB. Long-term morbidity in children treated with fractionated high-dose-rate brachytherapy for soft tissue sarcomas. J Pediatr Hematol Oncol 2003; 25: 448-52.

40. Nag S, Martinez-Monge R, Ruymann F, et al. Innovation in the management of soft tissue sarcomas in infants and young children: high-dose-rate brachytherapy. J Clin Oncol 1997; 15: 3075-84.

41. Buwalda J, Blank LE, Schouwenburg PF, et al. The AMORE protocol as salvage treatment for non-orbital head and neck rhabdomyosarcoma in children. Eur $\mathrm{J}$ Surg Oncol 2004; 30: 884-92.

42. Buwalda J, Freling NJ, Blank LE, et al. AMORE protocol in pediatric head and neck rhabdomyosarcoma: descriptive analysis of failure patterns. Head Neck 2005; 27: 390-96.

43. Buwalda J, Schouwenburg PF, Blank LE, et al. A novel local treatment strategy for advanced stage head and neck rhabdomyosarcomas in children: results of the AMORE protocol. Eur J Cancer 2003; 39: 1594-602.

44. Haie-Meder C, Breton-Callu C, Oberlin O, et al. [Brachytherapy in the treatment of vesicoprostatic rhabdomyosarcomas in children]. Cancer Radiother 2000; 4 (suppl 1): S145-49 in French.

45. Haie-Meder C, Flamant F, Revillon Y, et al. [The role of brachytherapy in the therapeutic strategy of vesico-prostatic rhabdomyosarcoma in children]. Ann Urol (Paris) 1994; 28: 302-05 in French.

46. Flamant F, Gerbaulet A, Nihoul-Fekete C, et al. Long-term sequelae of conservative treatment by surgery, brachytherapy, and chemotherapy for vulval and vaginal rhabdomyosarcoma in children. J Clin Oncol 1990; 8: 1847-53.

47. Flamant F, Chassagne D, Cosset JM, et al. Embryonal rhabdomyosarcoma of the vagina in children: conservative treatment with curietherapy and chemotherapy. Eur J Cancer 1979; 15: 527-32.

48. Merchant TE, Parsh N, del Valle PL, et al. Brachytherapy for pediatric soft-tissue sarcoma. Int J Radiat Oncol Biol Phys 2000; 46: 427-32.

49. Cherlow JM, Syed AM, Puthawala A, et al. Endocurietherapy in pediatric oncology. Am J Pediatr Hematol Oncol 1990; 12: 155-59.

50. Zelefsky MJ, LaQuaglia MP, Harrison LB. Combination surgery and brachytherapy for pediatric soft tissue sarcomas. Endocurie Hypertherm Oncol 1993; 9: 50.

51. Martinez-Monge R, Garran C, Cambeiro M, et al. Feasibility report of conservative surgery, perioperative high-dose-rate brachytherapy (Phigh dose rateB), and low-to-moderate dose external beam radiation therapy (EBRT) in pediatric sarcomas. Brachytherapy 2004; 3: 196-200.

52. Guyatt GH, Cook DJ, Sackett DL, et al. Grades of recommendation for antithrombotic agents. Chest 1998; 114: S441-44.

53. Reis LAG, Eisner MP, Kosary CL, et al, eds. SEER Cancer Statistics Review, 1975-2002. National Cancer Institute. Bethesda. http://seer.cancer.gov/csr/1975_2002/, based on November, 2004 SEER data submission, posted to the SEER website 2005. 
54. Knoos T, Kristensen I, Nilsson P. Volumetric and dosimetric evaluation of radiation treatment plans: radiation conformity index. Int $\mathrm{J}$ Radiat Oncol Biol Phys 1998; 42: 1169-76.

55. Nag S, Fernandes PS, Martinez-Monge R, Ruymann FB. Use of brachytherapy to preserve function in children with soft-tissue sarcomas. Oncology 1999; 13: 36169.

56. Sklar CA. Overview of the effects of cancer therapies: the nature, scale and breadth of the problem. Acta Paediatr Suppl 1999; 88: 1-4.

57. Dorr W, Herrmann T. Cancer induction by radiotherapy: dose dependence and spatial relationship to irradiated volume. J Radiol Prot 2002; 22: A117-21.

58. Douglas BG, Fowler JF. The effect of multiple small doses of $x$ rays on skin reactions in the mouse and a basic interpretation. Radiat Res 1976; 66: 401-26. 


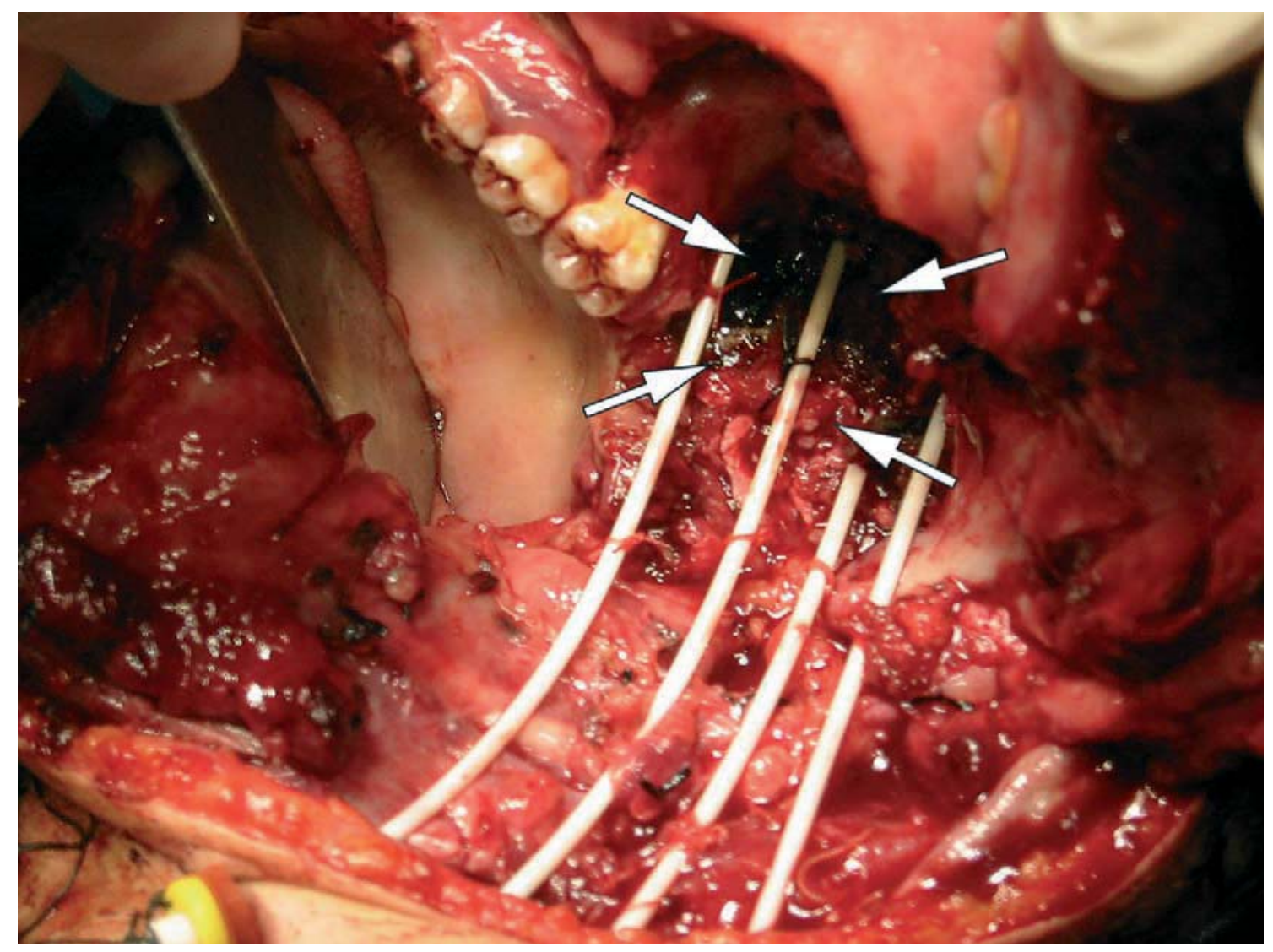

Figure 1. Fibrosarcoma in 9-year old boy. Fibrosarcoma in pterygoid space near carotid vessels was attached to pterygoid process on left side (arrows). 

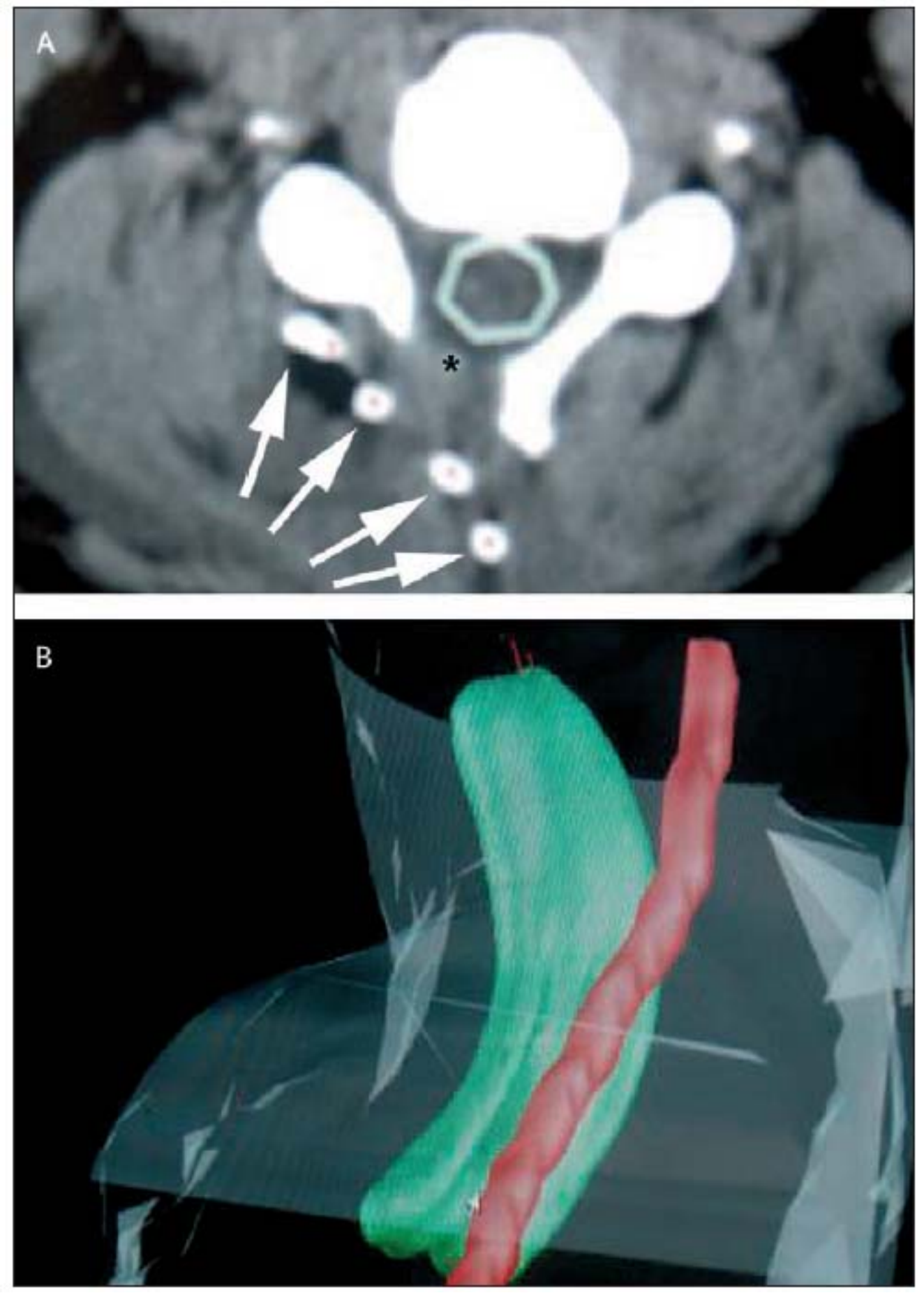

Figure 2. Recurrent paravertebral sarcoma. (A) Postoperative CT scan showing four afterloading catheters (arrows) placed in surgical bed for perioperative high-dose-rate brachytherapy. Posterior vertebral arc on right side was removed during surgery (asterisk). (B) Oblique view of threedimensional reconstruction at level of upper thorax and lower neck shows that brachytherapy isodose surface of $3 \mathrm{~Gy}$ (green) mostly spares spinal cord (red). 


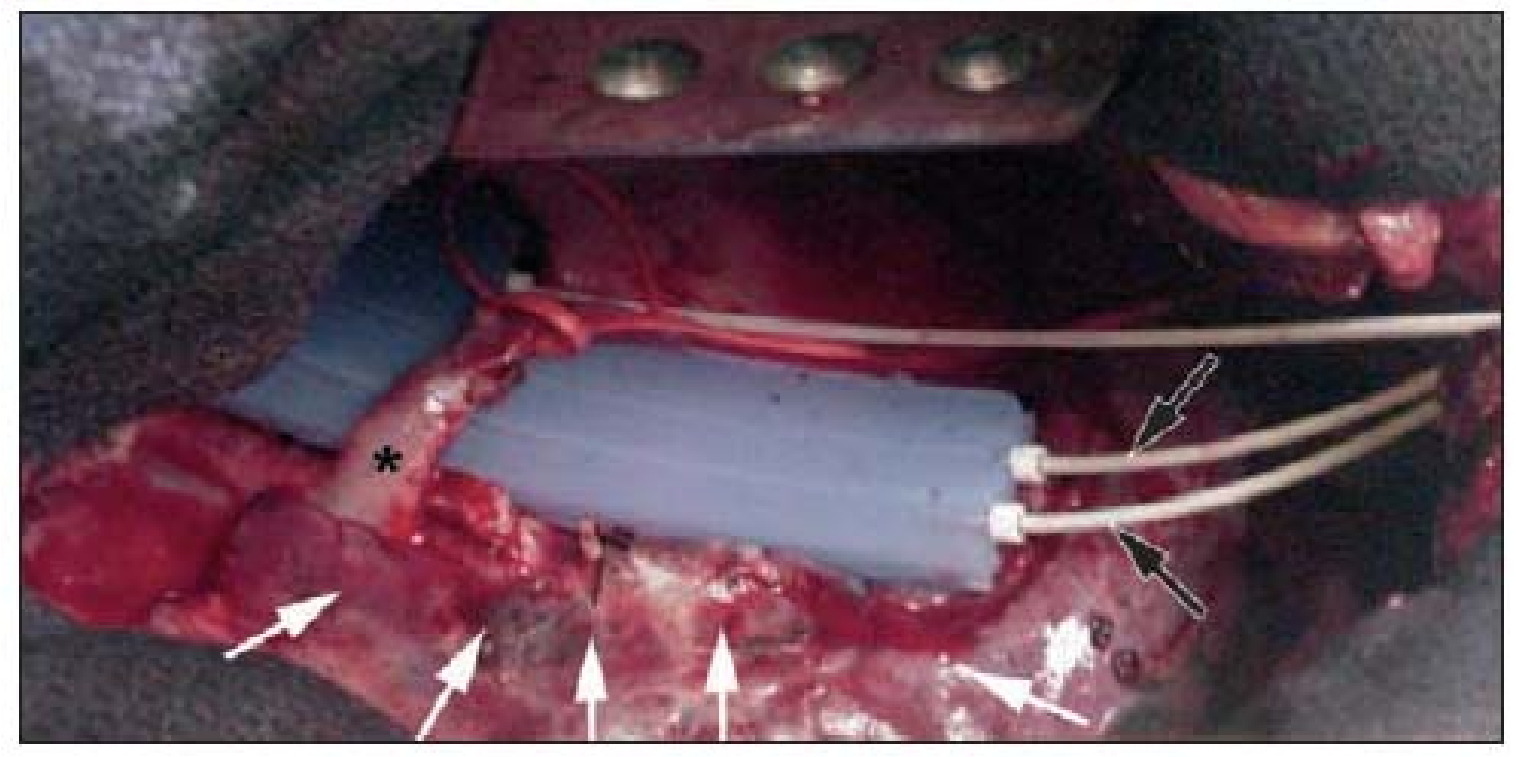

Figure 3. Intraoperative high dose rate brachytherapy for mediastinal Lymphadenopathy. A tissue-equivalent applicator (blue plastic material) with two afterloading catheters (black arrows) is secured against surgical surface. Applicator was positioned between azygos vein (asterisk) and mediastinum after resection of several right paratracheal nodes. Lung tissue (white arrows) is displaced from brachytherapy area with surgical retractors. 


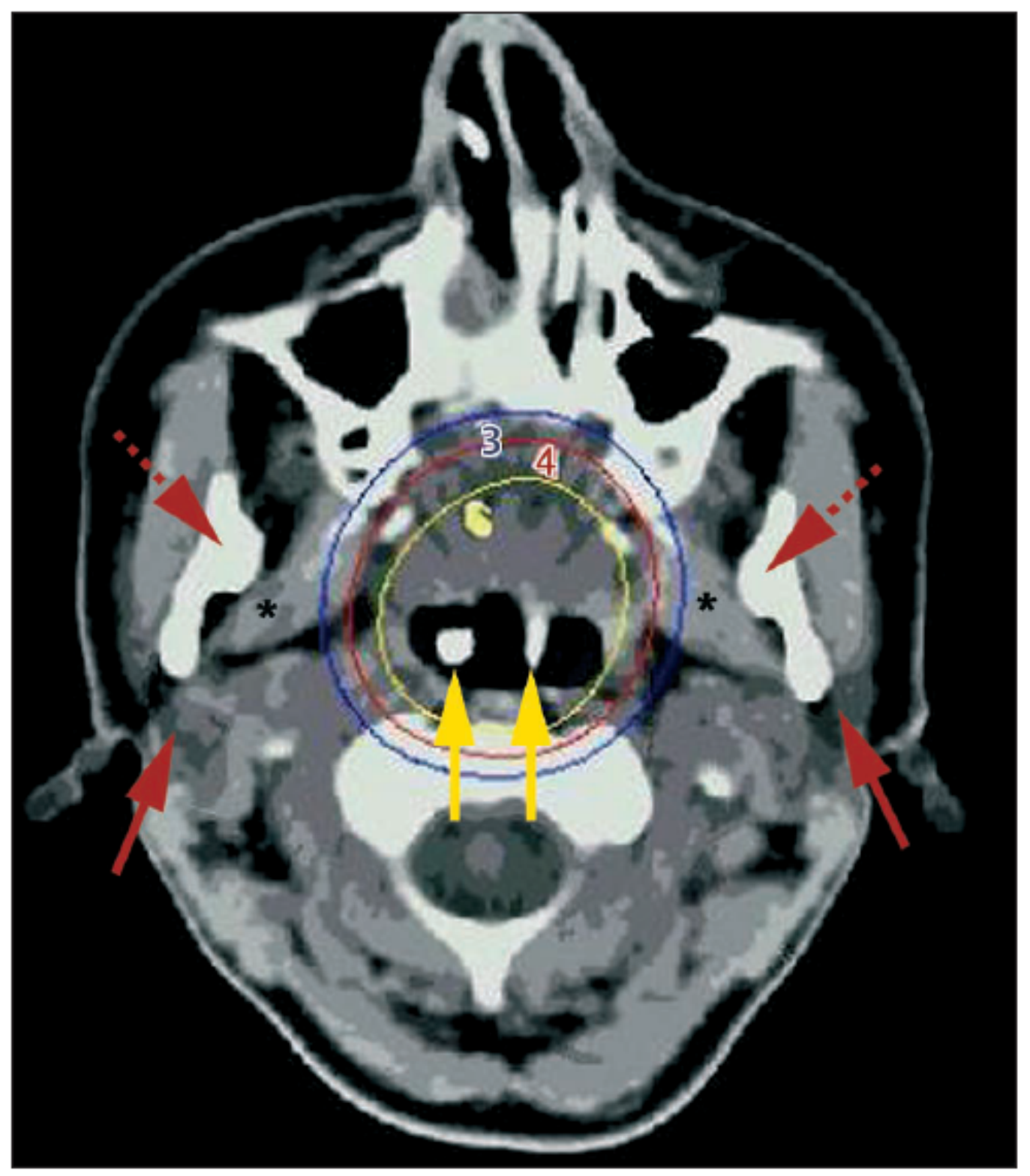

Figure 4. Target volume irradiated with brachytherapy in nasopharyngeal Carcinoma. Two flexible applicators (yellow arrows) are inserted through nose. Isodose lines of 3 Gy (blue circle), 4 Gy (red circle), and 6 Gy (yellow circle) are depicted in CT image. Radiotherapy of salivary glands (red solid arrows), masticatory muscles (asterisks), and mandible (red dotted arrows) is minimal. 


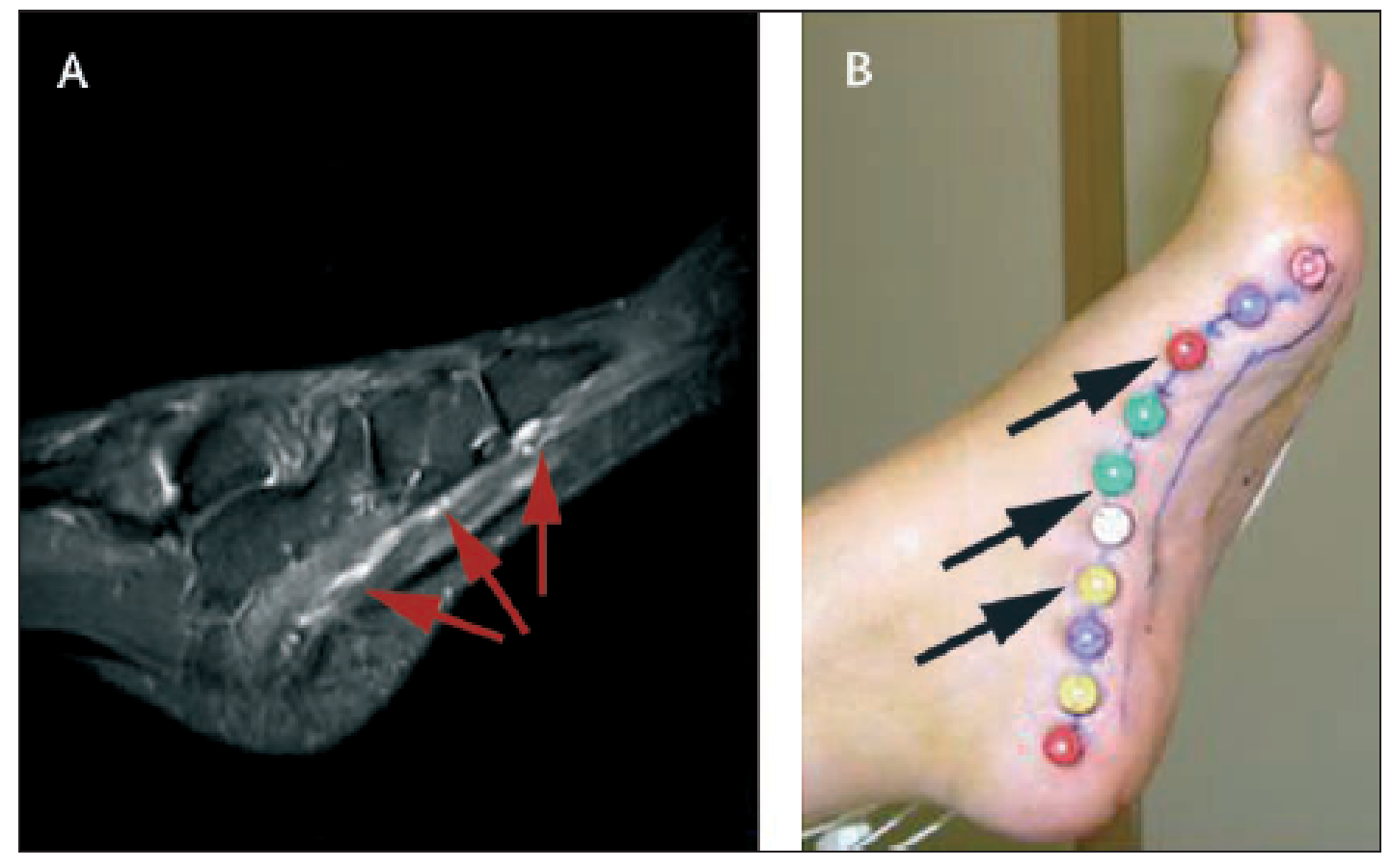

Figure 5. Alveolar rhabdomyosarcoma treated with brachytherapy after Chemotherapy. (A) Postchemotherapy MRI shows partial response (red arrows). (B) Conservative resection with perioperative high dose-rate brachytherapy. Colour buttons (arrows) secure afterloading catheters in entry and exit points at skin surface. 
Table 1. Results of low-dose-rate brachytherapy in children with brain tumours

\begin{tabular}{|c|c|c|c|c|c|c|}
\hline & $\mathrm{n}^{*}$ & $\begin{array}{l}\text { Age at brachytherapy } \\
\text { (median [range], years) }\end{array}$ & $\begin{array}{l}\text { Follow-up (median } \\
\text { [range], years) } \dagger\end{array}$ & Outcome‡ & $\begin{array}{l}\text { Moderate-severe } \\
\text { late eventss }\end{array}$ & Ref \\
\hline 90 Gy $^{129}$ (permanent) & $\begin{array}{l}\text { Astrocytoma: } 36 \text { grade } 1 ; 14 \text { grade } 2 ; 6 \text { grade } 3 . \\
\text { Glioblastoma multiforme: } 0\end{array}$ & $<18$ & 10 & $\begin{array}{l}\text { Astrocytoma: } 22 \cdot 2 \% \text { grade } 1 ; 21 \cdot 0 \% \text { grade } 2 \\
16 \cdot 7 \% \text { grade } 3 . \text { Glioblastoma multiforme: } 0\end{array}$ & NA & 21 \\
\hline 120 Gy ${ }^{209}$ Ir (permanent) & $\begin{array}{l}\text { Astrocytoma: } 33 \text { grade } 1 ; 13 \text { grade } 2 ; 3 \text { grade } 3 \text {. } \\
\text { Glioblastoma multiforme: } 0\end{array}$ & $<18$ & 10 & $\begin{array}{l}\text { Astrocytoma: } 54 \cdot 6 \% \text { grade } 1 ; 31 \cdot 5 \% \text { grade } 2 \text {; } \\
0 \text { grade 3. Glioblastoma multiforme: } 0\end{array}$ & NA & 21 \\
\hline $\begin{array}{l}49 \cdot 9 \text { Gy external-beam } \\
\text { radiotherapy then } \\
54 \cdot 3 \text { Gy }(31 \cdot 2-83 \cdot 3) \\
\text { temporary brachytherapy }\end{array}$ & $\begin{array}{l}\text { Primary: } 2 \text { glioblastoma multiforme; } \\
8 \text { high-grade non-glioblastoma multiforme; } \\
3 \text { contrast-enhancing low-grade non-glioblastoma } \\
\text { multiforme; } 2 \text { choroid plexus carcinoma. Recurrent: } \\
2 \text { glioblastoma multiforme; } 3 \text { high-grade } \\
\text { non-glioblastoma multiforme; } 7 \text { contrast-enhancing } \\
\text { low-grade non-glioblastoma multiforme; } 1 \text { metastatic } \\
\text { rhabdomyosarcoma }\end{array}$ & $12 \cdot 6(3-16 \cdot 8)$ & $9(5-12)$ & $\begin{array}{l}13 \text { survivors (and } 7 \text { of } 8 \text { with primary } \\
\text { high-grade non-glioblastoma multiforme); } \\
15 \text { local control }\end{array}$ & $\begin{array}{l}17 \text { of } 22 \text { necrosis } \| ; \\
0 \text { grade } 3-4\end{array}$ & $; 22$ \\
\hline $\begin{array}{l}\text { a are number of patient } \\
\text { ients who had been reo }\end{array}$ & $\begin{array}{l}\text { unless indicated otherwise. †Ages rounded to nearest year. } \$ 5 \text { - } \\
\text { :rated on. }\end{array}$ & 5-year survival unless othe & indicated. 5Only tc & ffects attributable to high-dose region treated with & th brachytherapy & \\
\hline
\end{tabular}

Table 2. Results of brachytherapy in children with clear-cell carcinoma, craniopharyngioma, Ewing's sarcoma or primitive neuroectodermal tumours, and neuroblastoma

\begin{tabular}{|c|c|c|c|c|c|c|}
\hline & $\mathbf{n}^{*}$ & $\begin{array}{l}\text { Age at brachytherapy } \\
\text { (median [range] } \\
\text { years) }\end{array}$ & $\begin{array}{l}\text { Follow-up } \\
\text { (median [range], } \\
\text { years) } \dagger\end{array}$ & Outcome & $\begin{array}{l}\text { Moderate-severe } \\
\text { late eventsf }\end{array}$ & Ref \\
\hline \multicolumn{7}{|l|}{ Clear-cell adenocarcinoma of vagina } \\
\hline $\begin{array}{l}60-65 \text { Gy temporary low dose rate brachytherapy } \\
\text { or } 15-25 \text { Gy temporary low dose rate brachytherapy } \\
\text { and } 40-50 \text { Gy external-beam radiotherapy }\end{array}$ & 27 & $15 \cdot 0(7-21)$ & $8(1-14)$ & $\begin{array}{l}\text { 5-year, } 88 \% \text {; node-negative survival } 95 \% \text {; } \\
\text { node-positive survival } 40 \% \text {; disease-free } \\
\text { survival } 78 \% ; 22 \text { patients alive (all with } \\
\text { vaginal preservation, } 20 \text { with uterine } \\
\text { preservation, and } 18 \text { with ovarian } \\
\text { preservation) }\end{array}$ & $35 \%$ grade $2-3$ & $23-25$ \\
\hline \multicolumn{7}{|l|}{ Craniopharyngioma } \\
\hline $\begin{array}{l}224 \text { Gy }(189-250) \text { permanent low dose rate } \\
\text { brachytherapy }\end{array}$ & $\begin{array}{l}25 \text { primary and } \\
24 \text { recurrent or } \\
\text { residual }\end{array}$ & $29(3-74) 5$ & 4 & $\begin{array}{l}\text { 10-year local control, } 70 \% \text {; } 10 \text {-year acturial } \\
\text { survival rate } 80 \% ; 5 \text {-year acturial survival } \\
\text { rate } 90 \% ; 19 \text { had improved visual function }\end{array}$ & I 3/40S all visual & 26 \\
\hline 200 Gy permanent low dose rate brachytherapy & 62 (78 cysts) & $17(4-71)$ & $12(2-16)$ & 10 -year, $62 / 78(79.5 \%)$ & $\begin{array}{l}3 \text { blindness; } 1 \text { worsening of } \\
\text { visual fields; } 1 \text { third-nerve } \\
\text { paralysis }(\mathrm{n}=1) ; 3 \text { diabetes } \\
\text { insipidus and/or } \\
\text { panhypopituitarism }\end{array}$ & 27 \\
\hline \multicolumn{7}{|c|}{ Ewing's s sarcoma or primitive neuroectodermal tumours } \\
\hline $\begin{array}{l}12 \text { Gy (4-15) intraoperative high dose rate } \\
\text { brachytherapy and } 36 \text { Gy (10-53) external-beam } \\
\text { radiotherapy }\end{array}$ & 9\|l & $7(0 \cdot 8-24)$ & $1(0-9)$ & $\begin{array}{l}\text { 2-year local control 56\%; 2-year overall } \\
\text { survival } 54 \%\end{array}$ & $\begin{array}{l}\text { 2-year complication rate, } \\
12 \% ; 2 \text { died from treatment- } \\
\text { related causes; } 1 \text { died of } \\
\text { postoperative complications }\end{array}$ & $28-30$ ฯ \\
\hline $\begin{array}{l}10-12 \text { Gy intraoperative high dose rate } \\
\text { brachytherapy and } 50-55 \text { Gy external-beam } \\
\text { radiotherapy }\end{array}$ & 6 & $17 \cdot 5(9-27)$ & $2(1-2)$ & 6 with local control & 0 & 31 \\
\hline $\begin{array}{l}10-15 \text { Gy intraoperative high dose rate } \\
\text { brachytherapy and } 27-30 \text { external-beam } \\
\text { radiotherapy }\end{array}$ & 4 & $9 \cdot 2(2-14)$ & $4(1-8)$ & 4 withy local control & None & 32,33 \\
\hline \multicolumn{7}{|l|}{ Nasopharyngeal carcinoma } \\
\hline $\begin{array}{l}5 \text { Gy high dose rate brachytherapy for two cycles } \\
\text { and } 55 \text { Gy external-beam radiotherapy }\end{array}$ & 16 & $14 \cdot 0(7-18)$ & $5(1-10)$ & $\begin{array}{l}\text { Local control, } 15 \text { patients; } 13 \text { patients } \\
\text { alive without disease }\end{array}$ & $\begin{array}{l}3 \text { hypothyroidism; } \\
3 \text { hypocausia; } 2 \text { trismus; } \\
1 \text { palatine hypomotility; } \\
1 \text { disturbance of facial growth }\end{array}$ & 34 \\
\hline \multicolumn{7}{|l|}{ Neuroblastoma } \\
\hline $\begin{array}{l}12 \text { Gy (4-15) intraoperative high dose rate } \\
\text { brachytherapy and } 36 \text { Gy (10-53) external-beam } \\
\text { radiotherapy }\end{array}$ & 16 & $7(0.8-24)$ & $1(0-9)$ & 2-year local control, $56 \%$ & 2-year, $12 \%$ & 28-30ศ \\
\hline \multicolumn{7}{|l|}{ Retinoblastoma } \\
\hline 40 Gy temporary low dose rate brachytherapy & $\begin{array}{l}208 \text { eyes in } \\
141 \text { children }\end{array}$ & 16 & $3(0-20)$ & 4-year local control, 172/208 (83\%) & $\begin{array}{l}\text { 5-year follow-up: } 27 \% \\
\text { non-proliferative retinopathy; } \\
15 \% \text { proliferative retinopathy; } \\
25 \% \text { maculopathy; } \\
26 \% \text { papillopathy; } \\
31 \% \text { cataract; } 11 \% \text { glaucoma }\end{array}$ & 35 \\
\hline $\begin{array}{l}44-0 \text { Gy }(35-0-47 \cdot 6) \text { temporary low dose rate } \\
\text { brachytherapy }\end{array}$ & 21 & $2(0.5)$ & $4(0-17)$ & $25 / 26^{* *}$ with local control & 1 & 36 \\
\hline
\end{tabular}


Table 3. Results of brachytherapy in children with rhabdomyosarcoma

\begin{tabular}{|c|c|c|c|c|c|c|}
\hline & $\mathbf{n}^{*}$ & $\begin{array}{l}\text { Age at brachytherapy } \\
\text { (median [range], } \\
\text { years) }\end{array}$ & $\begin{array}{l}\text { Follow-up } \\
\text { (median [range], } \\
\text { years)† }\end{array}$ & Outcome & $\begin{array}{l}\text { Moderate-severe } \\
\text { late eventsł }\end{array}$ & Ref \\
\hline \multicolumn{7}{|l|}{ Multiple locations } \\
\hline $\begin{array}{l}12(4-15) \text { Gy intraoperative high dose rate } \\
\text { brachytherapy and } 36 \text { Gy }(10-53) \\
\text { external-beam radiotherapy }\end{array}$ & 20 & $7(0-8-24)$ & $1(0-9)$ & 2-year local control, $56 \%$ & 2 -year, $12 \%$ & $28-305$ \\
\hline $\begin{array}{l}50.0 \text { Gy }(39-5-100.0) \text { temporary low dose rate } \\
\text { brachytherapy alone or } 50.0(25 \cdot 0-50 \cdot 0) \\
\text { temporary low dose rate brachytherapy with } \\
34-48 \text { Gy external-beam radiotherapy }\end{array}$ & $\begin{array}{l}7 \text { primary, } \\
7 \text { recurrent or } \\
\text { metastatic }\end{array}$ & $6 \cdot 0(1 \cdot 0-13 \cdot 0)$ & $3(0-10)$ & 10/14 achieved local control & 3 & 37 \\
\hline $\begin{array}{l}\text { 39.6-73-0 Gy temporary low dose rate } \\
\text { brachytherapy or } 100-0-170-0 \text { Gy } \\
\text { permanent low dose rate brachytherapy } \\
\text { (both with } 6.0[0.8-19.0] \text { external-beam } \\
\text { radiotherapy) }\end{array}$ & 8 & .. & $6(2-16)$ & 7 achieved local control & $\begin{array}{l}3 \text { of } 6 \text { patients followed up } \\
\text { for }>2 \text { years }\end{array}$ & 38 \\
\hline $\begin{array}{l}3 \text { Gy high dose rate brachytherapy for } \\
12 \text { cycles }\end{array}$ & 12 & $1.5(0.4-2.9)$ & $10(3-13)$ & $\begin{array}{l}10 \text { had locoregional control, } \\
2 \text { developed distant metastases }\end{array}$ & $\begin{array}{l}1 \text { trismus with bone necrosis, } \\
1 \text { vaginal stenosis, } \\
1 \text { periurethral fibrosis| }\end{array}$ & 39,40 \\
\hline $\begin{array}{l}10.0-12.5 \text { Gy intraoperative high dose rate } \\
\text { brachytherapy and } 0-45 \text { Gy external-beam } \\
\text { radiotherapy }\end{array}$ & 3 & $5.0(4 \cdot 0-12 \cdot 0)$ & $3(2-6)$ & 3 achieved local control & 0 & 32,33 \\
\hline \multicolumn{7}{|l|}{ Head and neck, non-orbital } \\
\hline $\begin{array}{l}69 \text { Gy temporary low dose rate brachytherapy } \\
\text { (primary tumour) or } 57 \text { Gy temporary low dose } \\
\text { rate brachytherapy (recurrent tumour) }\end{array}$ & 27 & $5 \cdot 1$ & NA & $\begin{array}{l}5 \text {-year local control of primary cases, } \\
84 \% ; 5 \text {-year local control of } \\
\text { recurrent cases, } 64 \%\end{array}$ & $39 \%$ & 235 \\
\hline $\begin{array}{l}\text { 30-50 Gy temporary low dose rate brachytherapy } \\
\text { (recurrent tumours) }\end{array}$ & $\begin{array}{l}5 \text { parameningeal; } \\
4 \text { non-parameningeal }\end{array}$ & $7.9(2 \cdot 4-9.9)$ & $6(4-10)$ & Locoregional control in 8 patients & 3 & 41 \\
\hline $\begin{array}{l}40-50 \text { Gy temporary low dose rate or pulsed dose } \\
\text { rate brachytherapy (primary tumours) }\end{array}$ & $\begin{array}{l}16 \text { parameningeal and } \\
6 \text { non-parameningeal }\end{array}$ & $4 \cdot 8(0 \cdot 5-12 \cdot 4)$ & $2 \cdot 8$ years $(0 \cdot 7-11 \cdot 1)$ & $\begin{array}{l}\text { Locoregional failure in } 7 \text { children } \\
\text { ( } 6 \text { in residual tumour region) }\end{array}$ & NA & 42 \\
\hline $\begin{array}{l}40-50 \text { Gy temporary low dose rate or pulsed dose } \\
\text { rate brachytherapy (primary tumours) }\end{array}$ & 20 & $5 \cdot 2(1 \cdot 2-12 \cdot 9)$ & $2 \cdot 6$ years $(0.7-10 \cdot 3)$ & $15 / 22$ locally controlled & 10 & 43 \\
\hline \multicolumn{7}{|l|}{ Vesico-prostatic } \\
\hline $\begin{array}{l}51 \cdot 2 \text { Gy }(14-65) \text { temporary low dose rate } \\
\text { brachytherapy or } 14-29 \text { Gy temporary low dose } \\
\text { rate brachytherapy and } 30-45 \text { Gy external-beam } \\
\text { radiotherapy }\end{array}$ & $\begin{array}{l}19 \text { brachytherapy; } \\
4 \text { brachytherapy and } \\
\text { external-beam } \\
\text { radiotherapy }\end{array}$ & $4.9(0.5-15)$ & $9(5-19)$ & 13 locoregional control & No grade 2 or higher & $2,44,45$ \\
\hline \multicolumn{7}{|l|}{ Vulvovaginal } \\
\hline $\begin{array}{l}60 \cdot 8 \text { Gy }(36-0-75-0) \text { temporary low dose rate } \\
\text { brachytherapy }\end{array}$ & 17 & $2(1-14)$ & $13(11-19)$ & 17 locoregional control & $\begin{array}{l}4 \text { (colorectal, vaginal, } \\
\text { urethral, ureteral stenosis) }\end{array}$ & $25,46,47$ \\
\hline
\end{tabular}

Table 4. Results of brachytherapy in children with soft-tissue sarcoma

\begin{tabular}{|c|c|c|c|c|c|c|}
\hline & $\mathbf{n}^{*}$ & $\begin{array}{l}\text { Age at brachytherapy } \\
\text { (median [range], years) }\end{array}$ & $\begin{array}{l}\text { Follow-up } \\
\text { (median [range], years) } \dagger\end{array}$ & Outcome & $\begin{array}{l}\text { Moderate-severe } \\
\text { late events; }\end{array}$ & Ref \\
\hline Temporary low dose rate brachytherapy & 13 & NA & NA & 5-year local control, $61 \%$ & 5 -year, $23 \%$ & 22 \\
\hline $\begin{array}{l}50 \text { Gy }(40-160) \text { temporary or permanent low dose rate } \\
\text { brachytherapy alone or } 25 \text { Gy }(15-40) \text { temporary or } \\
\text { permanent low dose rate brachytherapy and } 45 \text { Gy }(25-50) \\
\text { external-beam radiotherapy }\end{array}$ & 31 & $11 \cdot 0(1 \cdot 0-21 \cdot 0)$ & $3(1-9)$ & 28 locoregional control & 3 & 47 \\
\hline 30-40 Gy temporary low dose rate brachytherapy & 4 & $12 \cdot 5(9-16)$ & $3(2-4)$ & 2 achieved local control & 1 & 48 \\
\hline $\begin{array}{l}45 \text { Gy }(14-60) \text { temporary low dose rate brachytherapy, } \\
\text { and external-beam radiotherapy to eight patients }\end{array}$ & 225 & $16(3-18)$ & 4 & $\begin{array}{l}\text { 5-year acturial control, } \\
18 / 32(68 \%)\end{array}$ & 0 & 49 \\
\hline $\begin{array}{l}4 \text { Gy high dose rate brachytherapy for four or six cycles } \\
\text { and } 27 \text { or } 45 \text { Gy external-beam radiotherapy }\end{array}$ & 5 & $11(7-16)$ & $2(1-4)$ & 5 achieved local control & 0 & 50 \\
\hline
\end{tabular}

